Klyon A., Yefremenko V., Tochonov I.

\title{
SUSTAINABLE DEVELOPMENT ECONOMY: DETERMINATION OF ENERGY EFFICIENCY OF PRIVATE HOUSES ON THE BASIS OF DATA ON HEAT GAS CONSUMPTION
}

\begin{abstract}
Проаналізовані статистичні дані про витрати газу на опалення приватними домогосподарствами країн СНД. Запропонована методика оцінки енергоефективності приватного будинку на підставі середніх показників витрати газу за опалювальний сезон. Визначені питання кількісної оцінки теплової енергї та енергоресурсів, які витрачаються на опалення приватного будинку.

Ключові слова: енергоефективність приватного будинку, витрати газу на опалення, кількісна оцінка теплової енергї та енергоресурсів.
\end{abstract}

\section{Introduction}

The heating and ventilation of a private house takes about $72 \%$ of all energy resources it has spent [1]. Reducing the cost of heating will significantly reduce the cost of maintaining the house. It is for this reason, and especially in recent years, when energy prices in Ukraine have reached the world level, many owners of private houses have become actively interested in energy efficiency issues, which can serve as a guarantee of sustainable development of the state economy.

The homeowners with the heating system that uses natural gas as fuel are asked: what gas consumption per unit of heated area are considered «normal», and what measures need to be taken to reduce real consumption at the same «normal» level?

This article is devoted to answers to these questions of ordinary consumers.

\section{The object of research and its technological audit}

The object of this research is the energy efficiency of private houses as a guarantee of sustainable development of the state economy. To reduce the cost of heating the buildings on the basis of data on gas consumption, a study was made of the energy efficiency of a private house based on the average gas consumption figures for the heating season on the basis of the initial data [2]. In light of the most famous researchers who dealt with energy efficiency and energy conservation, [3-7], as well as the widespread Internet resources Consumption of energy [8], Shedding light on energy in the EU [9].

When considering the problem of energy saving in the housing and communal sector in the world practice, the main attention is usually paid to energy saving in the heating season, when their consumption is maximized. That is why it is necessary to take an example from countries such as the United States, China, the United Kingdom, Switzerland, the European Union countries that are ac- tively engaged in energy efficiency and energy saving in order to save energy.

\section{The aim and objectives of research}

The aim of this article is formulation of criteria for assessing the energy efficiency degree of a private house based on data on gas consumption for heating.

To achieve this aim, the following tasks have been accomplished:

1. To analyze statistical data on gas consumption for heating by private households.

2. To propose a methodology for assessing the energy efficiency of a private house based on average gas consumption for a heating season.

\section{Research of existing solutions of the problem}

Many scientists and practitioners are engaged in research on heat energy and energy resources spent on heating buildings, energy efficiency and energy conservation. The paper [1] proposes an algorithm for conducting energy audits and measures to reduce the energy consumption of industrial enterprises in heating systems. General issues of energy efficiency and gas consumption in the heating season are considered by users of Internet resources [2-5, 8-10]. The economic efficiency of the use of network solar power plants in private households is calculated and presented in a scientific study of authors [11]. The authors [12] analyze the experience of using heating systems on the basis of heat generating units. General issues for the design of water heating systems are presented in [13]. The authors of the scientific study [14] propose a model and modification of the hierarchy analysis method for assessing the energy efficiency level. Output data and standards for thermal insulation of buildings can be taken from the DBN [15]. The real prospects for energy efficiency in the US are investigated by the National Academy of Sciences and the National Press Academy of Washington [16]. Interesting 
are the works of scientists from Switzerland who in 2016 studied energy conservation in temperate climates [6] and energy efficiency in China [7].

The analysis of literature sources shows that the consumption of heat energy for heating the house depends on many factors, the most important of which are:

- general architectural and building characteristics of

the building (primarily its area and volume);

- used materials in the construction and repair of construction, as well as heat insulation, which directly affect the heat loss of the building;

- the geographical location of the house that determines the difference in temperature inside and outside the room and affects the necessary power of the heating system;

- characteristics of heating and ventilation systems (type of systems, parameters of installed heating equipment and its efficiency).

Thus, to answer the question of what the «normal» gas consumption per unit of heated area should be, it is necessary to have a sufficiently large amount of data. And even in this case, the estimated consumption of energy resources will be only approximate, since some initial data (for example, the difference in temperature inside and outside the room, depends on climatic factors) are of a probabilistic nature.

However, the issue of quantitative evaluation of thermal energy and energy resources spent on heating a private house is of very important practical importance.

\section{Methods of research}

Statistical data on gas consumption for heating by private households obtained on the basis of entries left by users of the FORUMHOUSE Internet forum: Gas consumption for heating in winter [2].

This resource has been underway for several years, and for this time more than 350 people have shared their data on the gas expenses that are spent on heating. However, 253 records were selected for the study, containing at least four mandatory components: the geographical location of the house, its area, the observation period and, in fact, the consumption themselves (hourly, daily, monthly or seasonal). Additional characteristics taken into account during the study were the structural parameters of the house (construction technology, wall materials, floors, ceilings and roofs), the degree of its insulation (thermal insulation materials and their thickness were used), as well as the characteristics of the heating system and the parameters of its operation, the type of gas boiler, the exposed coolant temperature, the method of heat transfer - radiators or warm floors, the availability of automation, etc.).

Analysis of the geography of the houses in the study sample showed that the majority of them (more than $80 \%$ ) are located in the III climatic zone and nine Atlanticcontinental European regions according to the B. Alisov classification [17]. This includes the greater part of Ukraine (with the exception of the southern regions and the Crimea), Belarus and the European part of Russia. The remaining part of the houses is approximately in equal proportion in the more northern and in the more southern areas of the same climatic zone. Thus, it can be concluded that the data on the geographical coverage of houses are of an average nature.
The distribution of private houses along the heated area is shown in Table 1. As can be seen from the table, the largest number of houses that fell into the study has an area from 61 to $120 \mathrm{~m}^{2}$, which corresponds to the subjective perception of the concept of «average house». The second in number is a group of houses with an area of $121 \ldots 200 \mathrm{~m}^{2}$. The houses of both groups are about $72 \%$ of the sample.

Table 1

Distribution of private houses by heated area

\begin{tabular}{|l|c|c|c|c|c|}
\hline \multirow{2}{*}{$\begin{array}{l}\text { Distribution of } \\
\text { private houses }\end{array}$} & \multicolumn{4}{|c|}{ Groups of houses by heated area, $\mathrm{m}^{2}$} & \multirow{2}{*}{ Total } \\
\cline { 2 - 5 } & $30 \ldots 60$ & $61 \ldots 120$ & $121 \ldots 200$ & $\begin{array}{c}\text { More } \\
\text { than 200 }\end{array}$ & \\
\hline $\begin{array}{l}\text { Absolute number } \\
\text { of houses in the } \\
\text { group }\end{array}$ & 16 & 99 & 83 & 55 & 253 \\
\hline $\begin{array}{l}\text { Relative number } \\
\text { of houses in the } \\
\text { group, \% }\end{array}$ & 6.3 & 39.15 & 32.8 & 21.75 & 100 \\
\hline
\end{tabular}

All the data on consumption were reduced to one indicator - the average gas consumption for heating for the entire heating season. The difficulty was that in addition to seasonal, homeowners also indicated hourly, daily and monthly consumption, while clarifying the climatic conditions in the observable period (Table 2). Often there were cases when consumption indicated for several periods (duplicated), most often - day and month or month and the entire heating period. In addition, the statistics of some homeowners contained a detailed report on gas consumption for all months of the heating season. The latter allowed to compose the average relative intensity of use of the heating system in the heating season (Table 3). According to the table below, the winter months are the coldest, and the heating system during this period works with the greatest intensity, conditionally taken as one. During the transition period (November and March), the heating system is used on average by $75 \%$, and at the beginning and at the end of the heating season (October and April) - by $50 \%$. The total intensity of use of the heating season for the season is 5.5 , at the same time the total number of months in the heating season is 7 .

Table 2

Distribution of data on gas consumption for heating, depending on the observation period*

\begin{tabular}{|l|c|c|c|c|c|}
\hline \multirow{2}{*}{$\begin{array}{c}\text { Data on gas con- } \\
\text { sumption }\end{array}$} & \multicolumn{3}{|c|}{ Period of observation of consumption } & \multirow{2}{*}{ Total } \\
\cline { 2 - 5 } & Hourly & Daily & Monthly & Seasonal & \\
\hline $\begin{array}{l}\text { Absolute number of } \\
\text { observations }\end{array}$ & 3 & 110 & 99 & 41 & 253 \\
\hline $\begin{array}{l}\text { Relative number of } \\
\text { observations, \% }\end{array}$ & 1.2 & 43.5 & 39.1 & 16.2 & 100 \\
\hline
\end{tabular}

Note: ${ }^{*}$ - excluding data duplication.

Table 3 
The method of recalculation of hourly, daily and monthly indicators into seasonal ones is given in Table 4.

Table 4

Method of recalculation of hourly, daily and monthly indicators into seasonal

\begin{tabular}{|c|c|c|}
\hline \multicolumn{2}{|c|}{ Output } & $\begin{array}{c}\text { The formula for the transition } \\
\text { to seasonal consumption }\end{array}$ \\
\hline Hourly consumption & H & $\mathrm{S}=\mathrm{H}^{*} 24^{*} 30^{*} \mathrm{I}$ \\
\hline Daily consumption & $\mathrm{D}$ & $\mathrm{S}=\mathrm{D}^{*} 30^{*} \mathrm{I}$ \\
\hline Monthly consumption & $\mathrm{M}$ & $\mathrm{A}=\mathrm{M}^{*} \mathrm{I}$ \\
\hline
\end{tabular}

Note: ${ }^{*}$ - the coefficient I is taken equal to 5.5 if the readings are taken in the cold months (December, January, February) and $8.8(5.5 /(0.5 \cdot(0.5+0.75))$ - in the off-season (October, November, March, April).

According to the received data, for all 253 houses in the sample, a diagram is constructed of the seasonal gas consumption for heating, depending on the heated area (Fig. 1). Fig. 2 provides a more informative diagram of unit consumption that illustrates the amount of cubic meters of gas spent by different households for heating one square meter of area during the entire heating season.

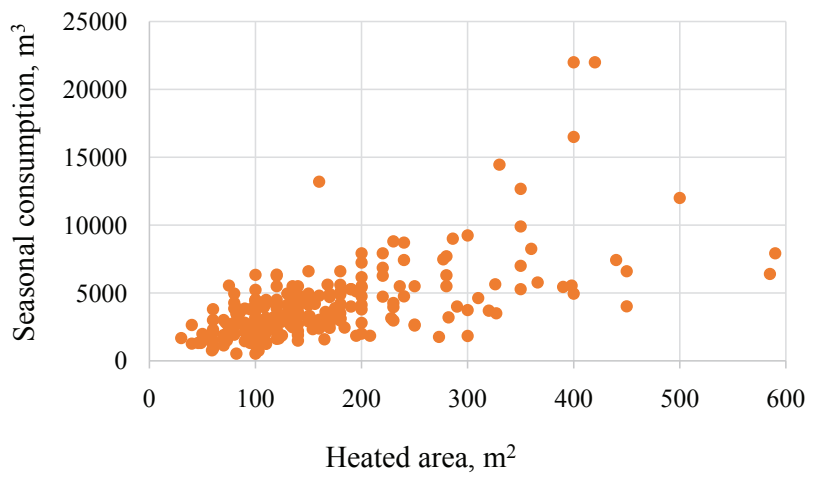

Fig. 1. Diagram of seasonal gas consumption for heating, depending on the heated area

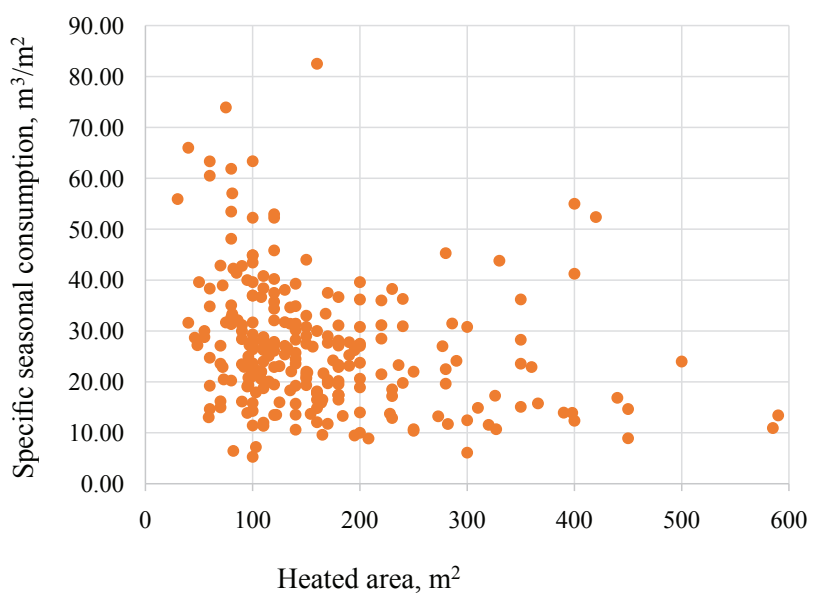

Fig. 2. The diagram of the specific seasonal gas consumption for heating

Fig. 3 shows a diagram of the specific monthly consumption of heating, obtained by dividing the values of seasonal consumption for 7 months of the heating period. This diagram allows to get the most averaged data on the consumption, taking into account the temperature fluctuations in the cold months and off-season.

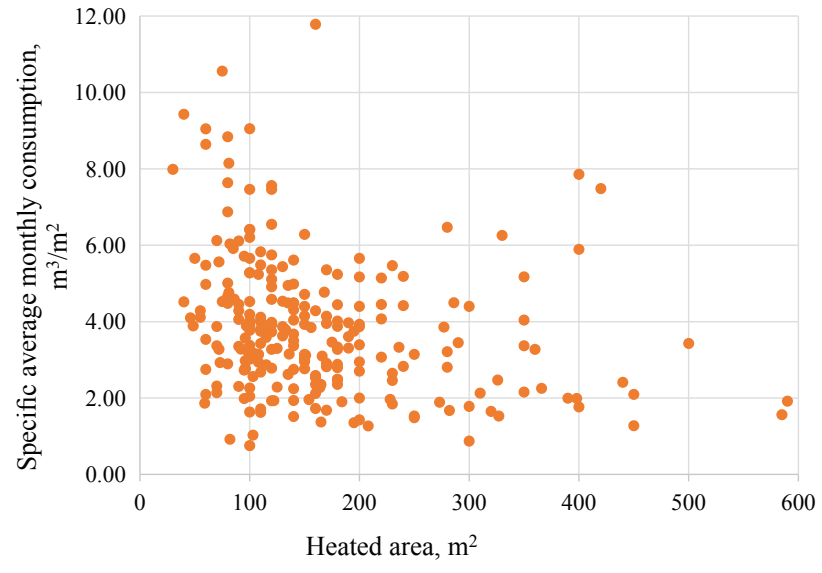

Fig. 3. Diagram of the specific average monthly gas consumption for heating

The main factor affecting the value of average monthly specific consumption, other things being equal, is the degree of house insulation, that is, its energy efficiency. Some role in the spread of data also contributes to the climatic factor, because even for the same geographical location the temperature in the same month from year to year varies.

Based on the analysis of average monthly specific consumption data, a classification of buildings according to the degree of their thermal insulation is proposed, given in Table 5.

Table 5

Classification of buildings by the insulation degree based on data on the specific average monthly gas consumption in the heating season

\begin{tabular}{|c|c|l|}
\hline $\begin{array}{c}\text { Class of the } \\
\text { house }\end{array}$ & $\begin{array}{c}\text { Specific average monthly } \\
\text { gas consumption, } \mathrm{m}^{3} / \mathrm{m}^{2}\end{array}$ & \multicolumn{1}{|c|}{$\begin{array}{c}\text { Characteristics of house } \\
\text { insulation }\end{array}$} \\
\hline A & Less than 2.0 & Wonderful insulation \\
\hline B & $2.0 . .2 .9$ & Excellent insulation \\
\hline C & $3.0 \ldots 3.9$ & Well insulation \\
\hline D & $4.0 \ldots 4.9$ & Satisfactory insulation \\
\hline E & $5.0 \ldots 7.0$ & Unsatisfactory insulation \\
\hline F & More than 7.0 & $\begin{array}{l}\text { Absence of insulation, heat loss } \\
\text { is unacceptable }\end{array}$ \\
\hline
\end{tabular}

According to the proposed method, all the houses that are included in the study are assigned to one or another class. Sometimes the same house, for which several values are given on the gas consumption in different observation periods, fell into several classes. In this case, when deciding whether the house belonged to a particular class, climatic conditions (the temperature difference inside and outside the room) are taken into account, at which gas flow measurements are made - Table 6. For example, according to observations for 2 months and calculating the average monthly specific gas consumption, the house belongs to class B. However, according to the data of the third month of observations and the corresponding average monthly gas consumption, the same house should be classed as C. At the same time, in the third month temperature drop, falls in the range of $45 \ldots 55^{\circ} \mathrm{C}$, which is much higher than the average value $\left(25 \ldots 35^{\circ} \mathrm{C}\right)$. So, if the temperature difference in the third month was not so high, but as average, then the gas consumption would be lower, and the house would most likely fall into class B. This circumstance allows to eventually classify the house in class B. 
Table 6

Gradation of months of temperature difference inside and outside the house

\begin{tabular}{|c|c|l|}
\hline $\begin{array}{c}\text { Color } \\
\text { designation }\end{array}$ & $\begin{array}{c}\text { Observed temperature } \\
\text { difference, }\end{array}$ & \multicolumn{1}{|c|}{ Characteristic of the month } \\
\hline & $45 \ldots 55$ & Extremely cold \\
\hline & $35 . .45$ & Very cold \\
\hline & $25 . .35$ & Cold (mean value of the difference) \\
\hline & $15 . .25$ & Off-season, relatively cold \\
\hline & $05 . .15$ & Off-season, relatively warm \\
\hline
\end{tabular}

Fig. 4 shows a histogram of the distribution of houses in the sample, according to the energy efficiency classes (degree of warming), depending on the average monthly gas consumption in the heating season.

Relative distribution of houses, according to the specific average monthly gas consumption, $\%$

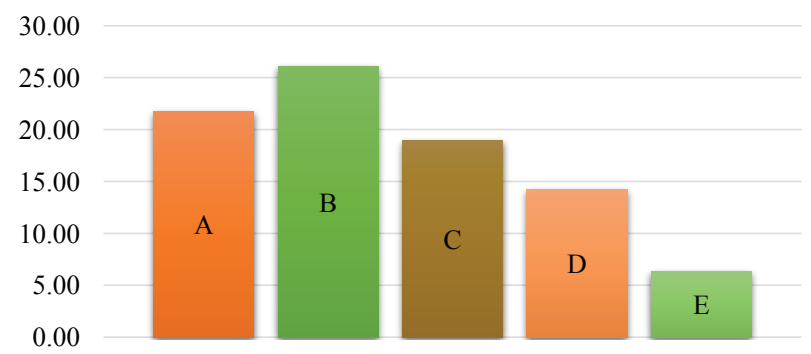

Fig. 4. Relative distribution of houses into the study, according to the specific average monthly gas consumption

Fig. 5 is a graph of the average monthly gas consumption for heating houses of different classes, depending on the heated area.

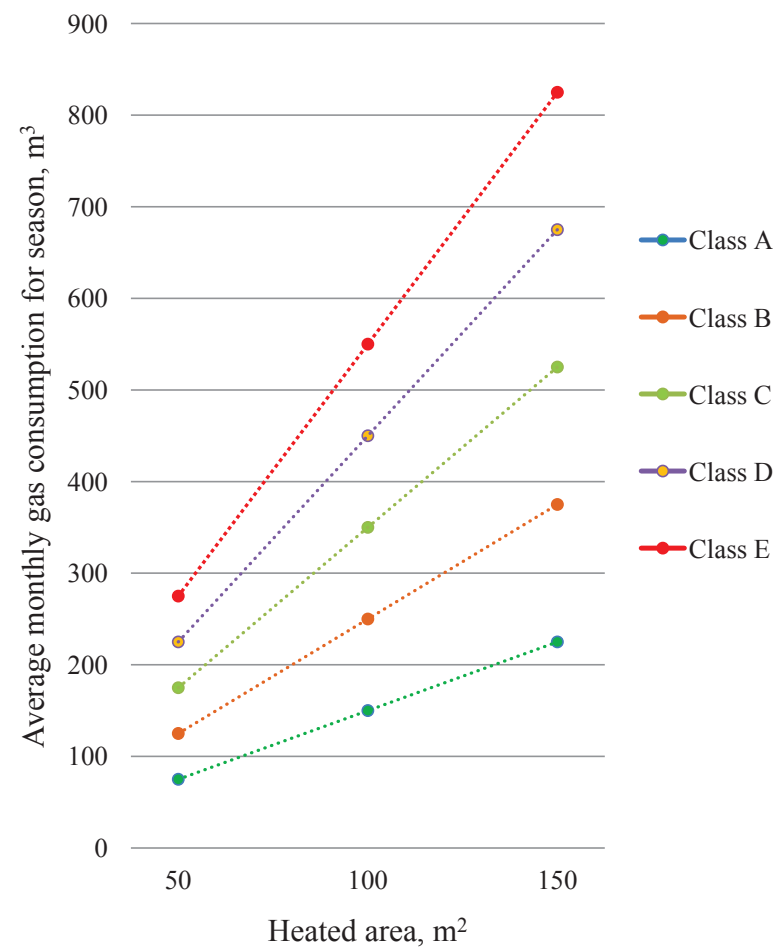

Fig. 5. Average monthly gas consumption for houses of various classes depending on the heated area
It can be seen from Fig. 5 that the most gas consumption for heating the house is carried by those consumers who have low house warming characteristics as described in Table 5 of the classification.

\section{Research results}

6.1. Analysis of seasonal gas consumption for heating, depending on the heated area. In the diagram in Fig. 1, it is possible once again make sure that most of the houses in the research have an area of up to $200 \mathrm{~m}^{2}$. Seasonal gas consumption of houses with the same area fluctuates within very wide limits, and with an increase in heated area, the range of variation in absolute values also increases.

6.2. Analysis of specific seasonal gas consumption for heating. The diagram in Fig. 2 shows that the seasonal gas consumption for heating the same area can vary by a factor of 5-6. Having constructed a regression line, it is possible to determine some average values of specific seasonal consumption, regardless of the heated area, are about $38 \mathrm{~m}^{3} / \mathrm{m}^{2}$. The corresponding monthly average specific gas consumption are $5.4 \mathrm{~m}^{3} / \mathrm{m}^{2}$. This value practically coincides with the subjective opinions of the participants of the forum [2], who assert that 4-5 cubic meters of gas are spent on heating on $1 \mathrm{~m}^{2}$ a month, while the consumption of about $3 \mathrm{~m}^{3} / \mathrm{m}^{2}$ indicates good insulation of the house.

6.3. Analysis of the average monthly gas consumption for heating. The diagram of Fig. 3 of the specific average monthly gas consumption for heating during the whole heating season (7 months) allows obtaining the most average data on consumption taking into account possible temperature variations in the cold months and off-season. It is for this reason that these data form the basis for classifying buildings according to the degree of warming in Table 5, characterizing their energy efficiency and economic feasibility.

6.4. Analysis of the relative distribution of houses by insulation classes. The histogram of Fig. 4 shows that about $60.5 \%$ of the houses taken into account in the study have well-insulated (classes A...C). Such high percentage of energyefficient houses is unlikely to be an arbitrary sample and is more likely related to the thematic focus of the forum [2]. Visitors to the forum are not random Internet users, but those who are interested in the topic of energy consumption for heating their houses. It is no coincidence that among the visitors of this forum a high percentage of those who have already taken real measures to reduce heating consumption have insulated their houses. At the same time, about $20.5 \%$ of houses in the sample are very high and even unacceptable heat loss from an economic point of view. Perhaps the owners of such houses after studying the information of other forum users will think and take measures to reduce energy consumption for heating.

6.5. Analysis of the factors affecting the energy efficiency of the house. Undoubtedly, the main factor determining the level of gas consumption for heating is the insulation degree of a private house. It is important to note that the maximum energy savings can be achieved only in the case of an integrated approach to insulation. Insufficient to insulate only the walls or the floor, it is necessary to eliminate all «weak spots» in the thermal insulation of the house: install energy-saving windows and doors, fully insulate the floors, walls and ceilings (roof). It is necessary to use high-quality thermal insulation materials, and their thickness should be calculated based on the standard values of heat losses and 
for these climatic conditions. In addition, it is very important to give sufficient attention to the efficiency of the heating system. The use of old gas boilers without timing (periodic shutdown of the gas burner), incorrect settings of heating equipment, inadequate heating system design can negate all efforts to warm the housing.

As shown by the study, the least gas consumption for heating is at house, built on modern wireframe technology, which just provides a comprehensive approach to energy conservation. All such houses that fall into the study sample belong to classes $\mathrm{A}$ and $\mathrm{B}$.

\section{SWOT analysis of research results}

Strengths. The strength of research is certain issues of quantitative evaluation of thermal energy and energy resources spent on heating a private house and analyzing the factors that affect the energy efficiency of a house.

Weaknesses. The weakness of research is that a high percentage of energy-efficient houses is unlikely to be an arbitrary sample and is more likely related to the thematic focus of the forum [2].

Opportunities. Opportunities for further research are borrowing the experience of foreign countries, which are actively engaged in energy efficiency and energy saving in order to save energy.

Threats. Threats to the results of the conducted researches are the understanding that the maximum energy savings can be achieved only in the case of an integrated approach to insulation, which is beyond the power of all consumers from an economic point of view.

\section{Conclusions}

1. The issues of the quantitative evaluation of thermal energy and energy resources spent for heating a private house are determined. The distribution of private houses on the heated area is carried out; distribution of data on gas consumption for heating, depending on the period of observation; the averaged relative intensity of use of the heating system for the season is calculated.

2. The proposed methodology for recalculating hourly, daily and monthly indicators into seasonal ones, taking into account the seasonality factor of the heating season. The classification of buildings according to the degree of their thermal insulation is developed on the basis of the analysis of the monthly average specific gas consumption in the heating season and the average monthly gas consumption for houses of various classes are calculated, depending on the heated area, on the basis of which it is possible to estimate the energy efficiency of private houses in the sample.

\section{References}

1. Jejula, V. V. Enerhoaudyt promyslovykh pidpryiemstv [Text] / V. V. JeJula, N. M. Slobodian // Visnyk Khmelnytskoho natsionalnoho universytetu. - 2011. - No. 1. - P. 56-58.

2. Rashod gaza na otoplenie zimoi [Electronic resource] // FORUMHOUSE. - 21.11.2017. - Available at: \www/URL: https://www.forumhouse.ru/threads/24702/

3. Hordeski, M. F. Dictionary of Energy Efficiency Technologies [Text] / M. F. Hordeski. - New York: Fairmont Press, 2004. 372 p. doi:10.4324/9780203021729

4. Solmes, L. A. Energy Efficiency [Text] / ed. by L. A. Solmes. Dordrecht: Springer, 2009. - 212 p. doi:10.1007/978-90-481-3321-5

5. Emre, M. CooperativeQ: Energy-efficient channel access based on cooperative reinforcement learning [Text] / M. Emre, G. Gur,
S. Bayhan, F. Alagoz // 2015 IEEE International Conference on Communication Workshop (ICCW), London, UK, June 8-12, 2015. - IEEE, 2015. doi:10.1109/iccw.2015.7247603

6. Boemi, S.-N. Energy Performance of Buildings [Text] / ed. by S.-N. Boemi, O. Irulegi, M. Santamouris. - Cham: Springer, 2016. - 543 p. doi:10.1007/978-3-319-20831-2

7. Wei, Y.-M. Energy Economics: Energy Efficiency in China [Text] / Y.-M. Wei, H. Liao. - Cham: Springer, 2016. - 339 p. doi:10.1007/978-3-319-44631-8

8. Consumption of energy [Electronic resource] // Eurostat Statistics Explained. - June 2017. - Available at: \www/URL: http://ec.europa.eu/eurostat/statistics-explained/index.php/ Consumption_of_energy

9. Shedding light on energy in the EU. A guided tour of energy statistics [Electronic resource] // Eurostat. - 2017. - Available at: \www/URL: http://ec.europa.eu/eurostat/cache/infographs/ energy/

10. Energoefektivnist [Electronic resource] // Teplo.gov.ua. - Available at: \www/URL: http://teplo.gov.ua/energoefektivnist

11. Klyon, A. Economic efficiency of network-based solar power stations employment in private housing estates [Text] / A. Klyon, V. Yefremenko // Technology audit and production reserves. - 2015. Vol. 3, No. 1 (23). - P. 8-13. doi:10.15587/2312-8372.2015.42789

12. Kovalov, S. Experience in the use of heating systems based on heat-generating units [Text] / S. Kovalov, M. Ovcharenko, A. Papchenko // Eastern-European Journal of Enterprise Technologies. - 2012. - Vol. 5, No. 8 (59). - P. 58-60. - Available at: \www/URL: http://journals.uran.ua/eejet/article/view/4616

13. Liubarets, O. P. Proektuvannia system vodianoho opalennia: posibnyk dlia proektuvalnykiv, inzheneriv i studentiv tekhnichnykh VNZ [Text] / O. P. Liubarets, O. M. Zaitsev, V. O. Liubarets. Viden - Kyiv - Simferopol, 2010. - 200 p.

14. Marhasov, D. Development of a model and modification of the hierarchy analysis method for energy efficiency level estimation [Text] / D. Marhasov, E. Sakhno, I. Skiter // EasternEuropean Journal of Enterprise Technologies. - 2015. - Vol. 5 , No. 2 (77). - P. 26-32. doi:10.15587/1729-4061.2015.51027

15. DBN V.2.6-31:2006. Teplova izoliatsiia budivel [Text] / Minbud Ukrainy. - Kyiv: Ukrarkhbudinform, 2006. - 65 p.

16. Real Prospects for Energy Efficiency in the United States [Text]/ National Academy of Sciences, National Academy of Engineering, and National Research Council. - Washington, DC: The National Academies Press, 2010. - 348 p. doi:10.17226/12621

17. Hromov, S. P. Meteorologiia i klimatologiia [Text]: Handbook S. P. Hromov, M. A. Petrosiants. - Ed. 7. - Moscow: Nauka, 2006. - 582 p.

\section{ЗКОНОМИКА УСТОЙЧИВОГО РАЗВИТИЯ: ОПРЕДЕЛЕНИЕ ЗНЕРГОЗФФЕКТИВНОСТИ ЧАСТНЫХ ДОМОВ НА ОСНОВЕ ДАННЫХ О РАСХОДЕ ГАЗА НА ОТОЛЛЕНИЕ}

Проанализированы статистические данные о расходе газа на отопление частными домохозяйствами стран СНГ. Предложена методика оценки энергоэффективности частного дома на основе усредненных показателей расхода газа за отопительный сезон. Определены вопросы количественной оценки тепловой энергии и энергоресурсов, расходуемых на отопление частного дома.

Kлючевые слова: энергоэффективность частного дома, расход газа на отопление, количественная оценка тепловой энергии и энергоресурсов.

Klyon Andrij, PhD, Senior Lecturer, Department of Handling, Construction and Road Construction Machinery and Equipment, Motor Vehicles and Vehicle Fleet, Donbas National Academy of Civil Engineering and Architecture, Kramatorsk, Ukraine, e-mail: admin@donnaba.edu.ua, ORCID: http://orcid.org/00000002-5105-0783

Yefremenko Viktoria, PhD, Associate Professor, Department of Economics and Management, Donbas National Academy of Civil Engineering and Architecture, Kramatorsk, Ukraine, e-mail: v.v.efremenko@donnaba.edu.ua, ORCID: http://orcid.org/00000003-4407-0767

Tochonov Igor, PhD, Associate Professor, Department of Economics and Management, Donbas National Academy of Civil Engineering and Architecture, Kramatorsk, Ukraine, e-mail:tmkc0001@gmail.com, ORCID: http://orcid.org/0000-0003-0251-2395 